\title{
Analyzing the Off-Grid Performance of the Hybrid Photovoltaic/Diesel Energy System for a Peripheral Village
}

\author{
Ahmed I. M. Iskanderani $\mathbb{D}^{1}{ }^{1}$ Ibrahim M. Mehedi $\mathbb{D},{ }^{1,2}$ Makbul A. M. Ramli $\mathbb{D}^{1}$ \\ and Md. Rafiqul Islam $\mathbb{D}^{3}$ \\ ${ }^{1}$ Department of Electrical and Computer Engineering (ECE) King Abdulaziz University, Jeddah 21589, Saudi Arabia \\ ${ }^{2}$ Center of Excellence in Intelligent Engineering Systems (CEIES) King Abdulaziz University, Jeddah 21589, Saudi Arabia \\ ${ }^{3}$ Department of Electrical and Electronic Engineering, Khulna University of Engineering and Technology, Khulna, Bangladesh
}

Correspondence should be addressed to Ibrahim M. Mehedi; imehedi@kau.edu.sa

Received 16 February 2020; Revised 27 May 2020; Accepted 30 July 2020; Published 17 August 2020

Academic Editor: Francesco Riganti-Fulginei

Copyright (c) 2020 Ahmed I. M. Iskanderani et al. This is an open access article distributed under the Creative Commons Attribution License, which permits unrestricted use, distribution, and reproduction in any medium, provided the original work is properly cited.

\begin{abstract}
Grid extension from the distribution network is being used to meet the demand for rural electricity all over the world. Due to the extra cost of extending electric lines to rural villages, it is not feasible as the installing and commissioning costs are directly related to several constraints such as distance from the main grid, the land location, utilities to be used, and the size of the approximate load. Consequently, it becomes a challenge to apply technoeconomic strategies for rural electrification. Therefore, considering the above issues of rural electrification through grid power, the renewable energy system can be an attractive solution. This research analyzes different types of loads considering domestic, industrial, and agricultural requirements for a remote village in a developing country like Bangladesh. In this paper, four types of demand scenarios are developed considering the income level of inhabitants of the village. The investigation identifies the optimal scope for renewable energy-based electrification and provides a suitable technoeconomic analysis with the help of HOMER software. The obtained results show that a combined architecture containing solar panel, diesel generator, and battery power is a viable solution and economically beneficial. The optimal configuration suggested for the primary scenario consists of $25 \mathrm{~kW}$ diesel generators to fulfill the basic demand. The hybrid PV-diesel-battery system becomes the optimal solution while the demand restriction is removed for secondary, tertiary, and full-option scenarios. Commercial and productive loads are considered in the load profile for these three scenarios of supply. For the primary scenario of supply, the electricity cost remains high as $\$ 0.449 / \mathrm{kWh}$. On the other hand, the lowest electricity cost ( $\$ 0.30 / \mathrm{kWh})$ is obtained for the secondary scenario. Although the suggested optimal PV-diesel-battery might not reduce the cost of electricity (COE) and NPC significantly, it is capable to reduce dependency on diesel utilization. Hence, the emission of carbon is reduced due to less utilization of diesel that helps to minimize the greenhouse effect on the environment.
\end{abstract}

\section{Introduction}

It is a challenge to supply electricity properly to the rural or isolated areas in a country. It depends on different situations such as the distance from country grid lines, tough weather conditions, and difficulties arising due to rough terrains in the way to the destination area. The selection of certain technology for power generation [1] or combination of technology for rural electrification is mostly contingent on the concerned place, its area, number of residents, manufacturing companies, learning hubs, medical clinics, obtainability of resources, etc. [2-5]. For the electrification of the rural areas, the normally considered are the diesel generator, batteries, LPG, biomass mechanism, and grid extension. Among these alternatives, grid extension mode 12 is one of the major means of electrification in rural areas [6].

The communal and monetary development of a country mostly depends on the electrification of rural areas, because 
the lack of electricity in a rural area can enhance poverty and quality of education can be affected which has a great impact on the social environment. Renewable energy-based off-grid electric power distribution is more suitable than extending the existing grid for rural areas [7-9].

There are several works done on renewable energy solutions. The feasibility of using solar power, wind power, and diesel generating power configurations is investigated for a rural area in Nigeria [10]. An optimum architecture is proposed using HOMER software with the analysis of fuel consumption and $\mathrm{CO}_{2}$ reduction. But the investigation was confined within the basic necessity of the area rather than a creative view of energy utilization.

A comparison of the expense of electricity generation from diesel generator with the hydrogen energy storage system has been made using HOMER power design software, and the optimized size of the system has been proposed [11]. However, this study does not consider rural electrification.

A study for rural electrification is done for a community in Bangladesh with $24 \mathrm{~kW}$ base load while considering DG, hydrogen energy source, wind, and solar resources [12, 13]. The study focused mainly on the need for electricity in domestic use but not for other important needs of the village like irrigation, agriculture, small manufacturing facility, and mobile communication tower. Again, the load profiles are not in detail. Instead of HOMER modeling software, the RET screen is used by some authors for the feasibility study of a combined energy system for wind and solar resources [14-20]. Other authors gave preference on HOMER modeling software specifically for the viability study of renewable energy system [21-23]. Although RET screen is an efficient tool for feasibility analysis, the literature [24-29] discourages its use for hybrid renewable energy system combining wind and solar energy resources. Hybrid 2 is another tool for feasibility analysis of renewable energy system, but it has a limited focus on the prefeasibility investigation of the system [30]. On the other hand, HOMER provides the facility of complete investigations including optimization and sensitivity inquiry [13]. Therefore, HOMER is widely used for renewable energy system design and optimization research. In conclusion, some unresolved issues can be summarized as follows:

(1) Grid extension is not environmentally attractive for rural electrification. On the other hand, renewable energy systems can be a cost-effective source of energy but have reduced environmental impact $[15,16]$

(2) The study should not be confined only within the basic needs of a targeted area, but rather it should consider other aspects like agricultural, irrigation, small-capacity manufacturing facility, health care center, educational center, and mobile communication towers [23]

(3) The development of a country means that every modern facility should reach every corner of the country including rural areas. The social and economic development of a rural area mainly depends on the well-organized rural electrification [16]
(4) The architecture of the rural electrical power system should not be based on solving their domestic purposes. Planning of rural electrification should include the purpose of the productive use of energy as well

Electrifying the rural area is a significant issue for the communal and monetary development of a country. The implementation of any electrification project in the rural area which is far from the main network is the main concern on the economic analysis and feasibility study. To the best of our knowledge, there is no such study focusing on the need for electricity in domestic use as well as all other important needs such as irrigation, agriculture, small manufacturing facility, and mobile communication tower. The present study will provide sufficient information in favor of renewable energy systems as a cost-effective source of energy, and social and economic development of a rural area mainly depends on the well-organized rural electrification.

\section{Illustrative Layout of the Proposed Investigation}

Figure 1 shows a schematic diagram of this research work. A suitable rural area of the northern part of Bangladesh is traced which is not yet electrified. Then, the load profile assessment was conducted to identify all the ways to meet the electricity demand of that locality. The situation of the nearest grid lines is considered to investigate and classify the accessible energy resources to that rural village. All these collected data are used to design a feasible renewable energy system with the help of HOMER software. HOMER is used for complete investigations and to propose an optimization technoeconomic analysis. Technical properties and life cycle cost (LCC) are also analyzed. LCC consists of all maintenance and operation costs including installation and initial capital cost over the system lifetime.

\section{Village Electricity Model in Bangladesh}

3.1. Village Context. A nonelectrified village is chosen in Thakurgaon district under Rangpur division. Thakurgaon is $467 \mathrm{~km}$ from Dhaka towards the northwest corner of Bangladesh as shown in Figure 2. It is surrounded by Dinajpur district on its south and Panchagarh district and India on its east and west, respectively. The Himalayan plain land is a part of the district of Thakurgaon. There are six subdistricts under Thakurgaon. Among those, Haripur has the lowest level of electrification. Although the Palli Bidyut Samit (PBS) is supplying electricity in urban areas, most of the villages are still not electrified. Because of being situated at the farthest distance from the capital city, the rural areas of Haripur subdistrict are very poorly electrified.

According to a report published in a famous national English newspaper on 15 October 2015 [31], Haripur subdistrict has a total of 179 villages, among which 43 villages are considered as urban areas and having facility of a subdistrict town. The rest of the villages (136) are not electrified yet. According to the Haripur subdistrict statistics office, Haripur has 199.43 sq. kilometers of land area containing 1,47,947 


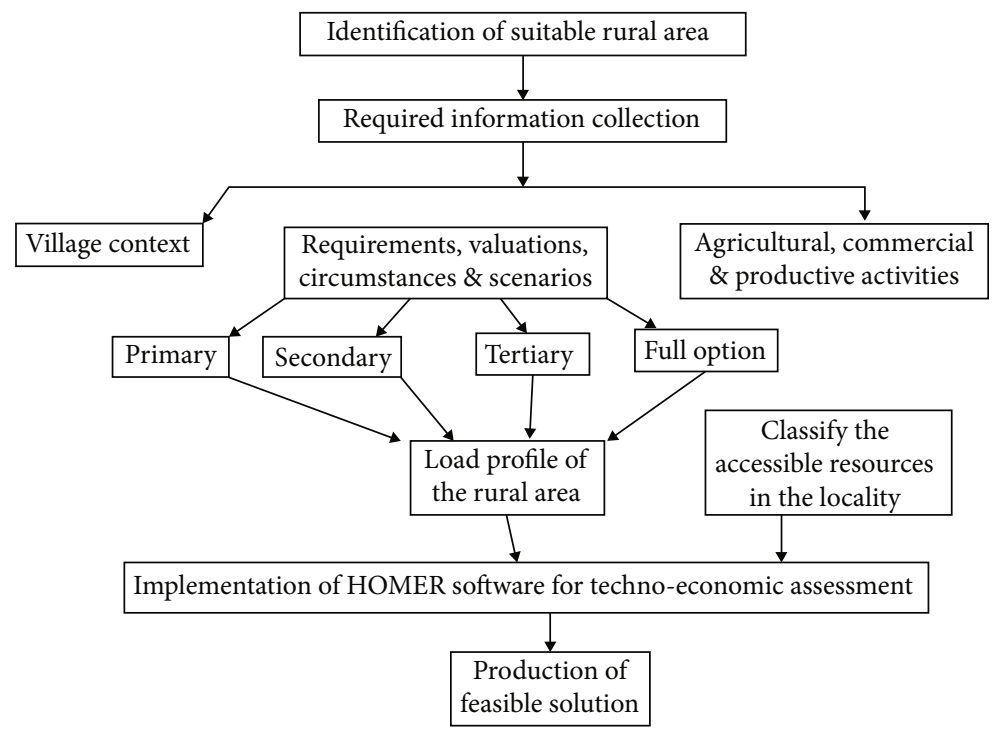

Figure 1: Work plan layout.

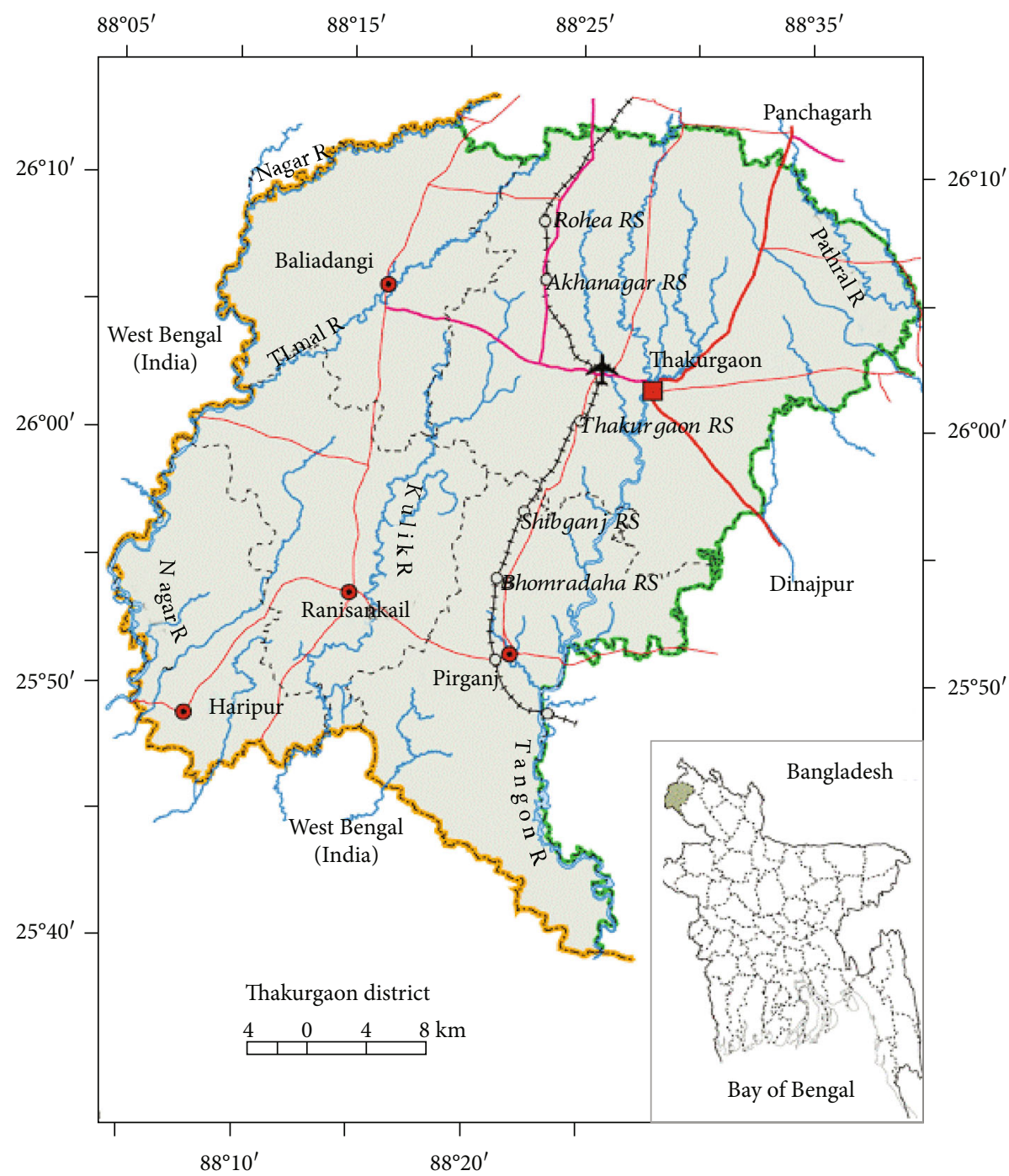

Figure 2: Geographical location of Thakurgaon district in Bangladesh. 


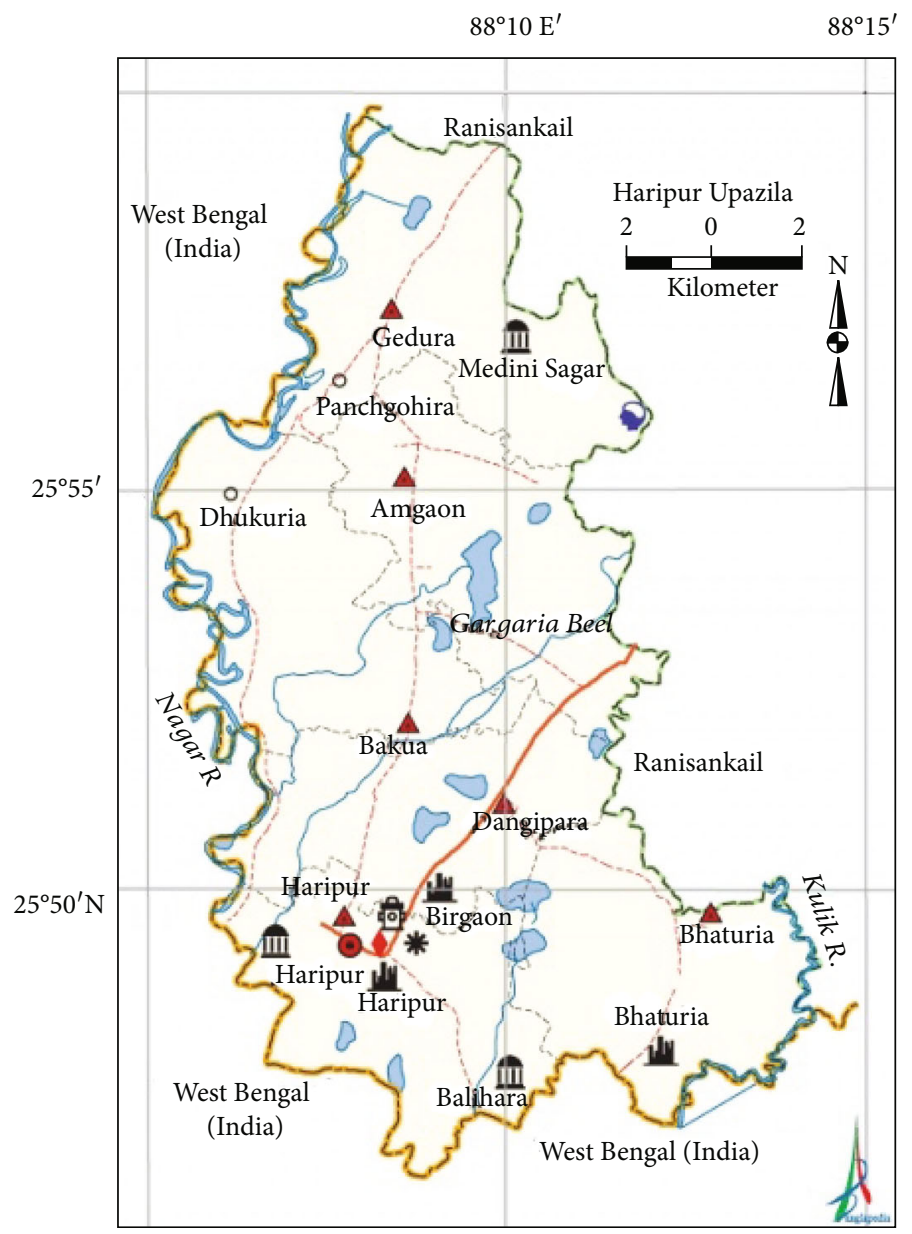

Figure 3: Geographical location of Haripur subdistrict [33].

inhabitants. More than 50000 students are enrolled in 168 different educational institutions like primary schools, secondary schools, colleges, and madrasa. Among those, 92 institutions have no electricity.

Nilgaon village is chosen for the current investigation. It is one of the rural villages of Amgaon union under Haripur subdistrict, and it is located at $25.91^{\circ} \mathrm{N}$ and $88.18^{\circ} \mathrm{E}$ as shown in Figures 3 and 4. It has 108 households with a total population of 468 people [32]. 165 are male and 172 are female aged 10 years and above. $4+$ is the average household size. Half of the houses are occupied with more than 5 family members, and a maximum of $1118+$ persons are living in $3.9 \%$ households. $45.6 \%$ of the total population can write a letter. In this village, there is a mixed community in terms of religion. 280 people are Muslims and 188 people are Hindus. 85.3\% houses are Kutcha type structured and the rest of households are based on Pucca structure. All the toilets are sanitary with a water seal. $39.3 \%$ of the 116 population is below 15 years old, and $7 \%$ of the population is above 60 years of age. Mainly the women take care of household works, and men are responsible for agricultural activities. The rural roads connect the village with two nearby bigger villages, Jamun and Nandagaon. In rainy seasons, part of the connected roads disappears. Kerosene and candles are mainly used for lighting because of being nonelectrified. Cooking energy demand is met by fuel wood, residues of agricultural products (e.g., paddy sticks and jute sticks), and cow-dung cakes. These are collected and procured locally.

3.2. Requirements, Valuations, and Circumstances. Nilgaon is an agricultural-dependent village. Due to its fertile soil, several crops are produced like paddy, jute, potato, wheat, and mustard seed. Various fruits are also supplied from the village such as banana, mango, papaya, and jackfruit. Fishing is also an important activity because of large water bodies, namely, ponds and lakes, being available in the village. However, the products of the village are consumed locally or sold at nearby markets and cannot be stored due to the lack of electricity [32-34]. As the village is nonelectrified, the electricity demand is unknown. But the above circumstances are used to make a range of demand possibilities as follows.

3.2.1. Primary. Primary service (outlying demand): the population of the village is divided into three basic groups among poor, middle-income, and rich households. Poor households are supposed to use electricity only for lighting purposes. Middle-income and rich households are assumed to utilize electricity for lighting, battery charging, fans, and TV. No productive use is considered in this primary service, and electric facility is provided for evening hours only. 
Google Maps Haripur Upazila

Nilgaon village $(25.91,88.18)$

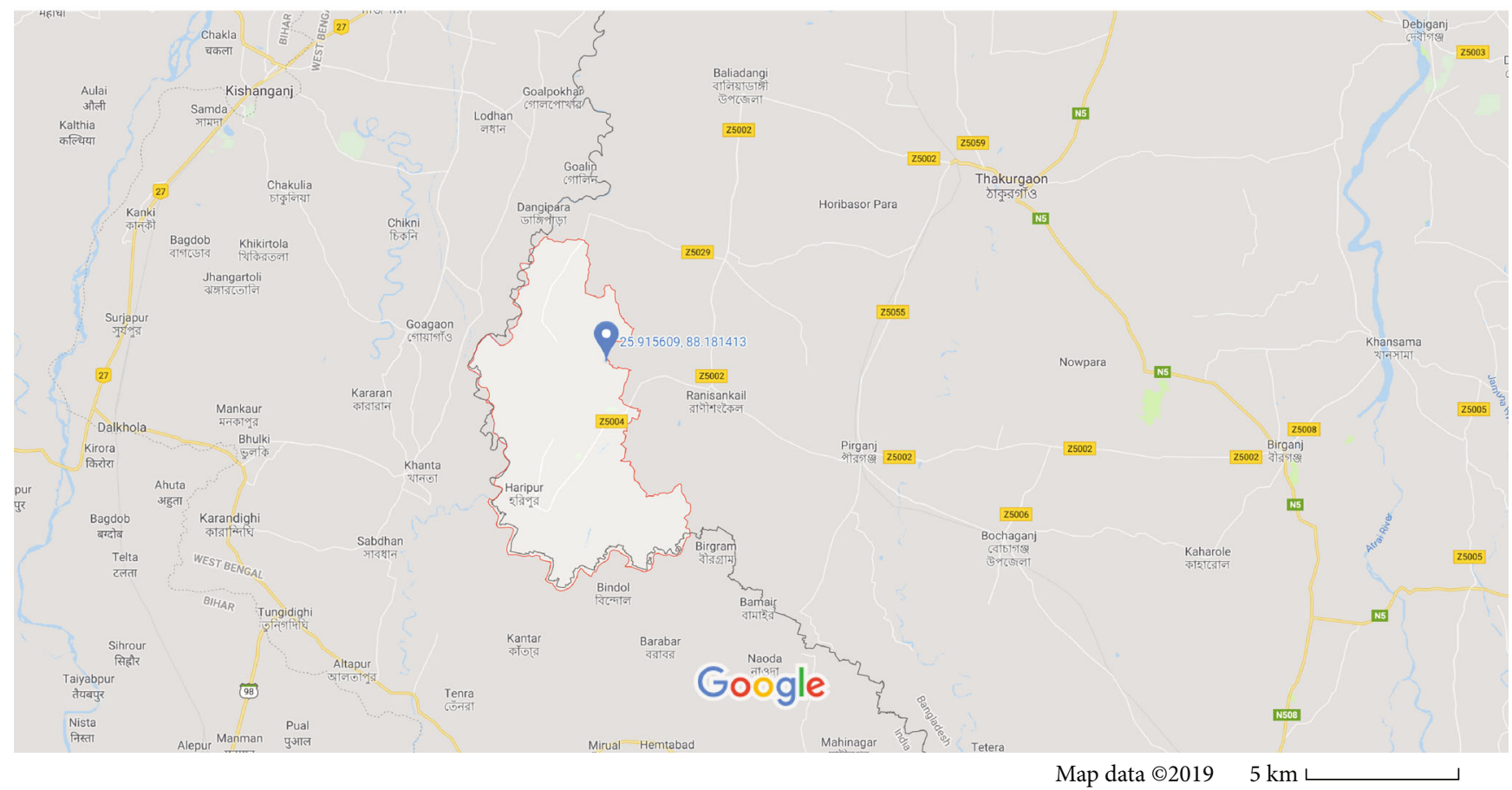

FIgURE 4: Geographical location of Nilgaon village in Haripur subdistrict.

3.2.2. Secondary. Productive demand is added in this scenario for which electricity is consumed at an off-peak time. These activities can include pumping water at night, food drying, grinding, and rice milling.

3.2.3. Tertiary. The third case of supply scenario satisfies all the demands of consumers at any time of the day, whether it is commercial or productive demand according to the necessity.

3.2.4. Full Option. It is the same as tertiary load scenario but with full option. The consumers do not have any restrictions. They have the facility for the highest demand of 24/7 supply. Many other cases can be studied, but in this paper, these four scenarios are considered for a proper understanding of a demand-supply situation and their effectiveness in terms of technoeconomic performance. Regarding the income limit, the poor households are expected to earn less than 7000 BDT/month, the middle-income households are considered to earn between $7000 \mathrm{BDT} / \mathrm{month}$ and $16000 \mathrm{BDT} / \mathrm{month}$, and the rich households are assumed to have an income more than $16000 \mathrm{BDT} / \mathrm{month}$. As per record, among the total 108 households of Nilgaon village, 16 households are rich, 50 households are poor, and the rest (42) of the households are in middle-income category [34]. Poor people are likely to spend $500 \mathrm{BDT} / \mathrm{month}$ for their electricity needs. Middle-income category people are likely to spend 600 $\mathrm{BDT} / \mathrm{month}$, and the rich households are expected to spend $800 \mathrm{BDT} / \mathrm{month}$ for the same purpose.
3.3. Different Scenarios of Electric Load Demand. An assumption of required load demand is presented in Table 1. It is important for the purpose of assessment. Four alternatives are considered here for different scenarios. These four different scenarios are further influenced by the economic condition of households. Electric loads are limited only for domestic purposes in the primary scenario for the evening use. Some commercial and productive loads are added in the evening and off-peak hours in the secondary scenario along with domestic demand. In tertiary and full option scenarios, increased domestic loads are estimated for extended operation hours according to the economic condition of poor, middle-income, and rich households. Further, the commercial load and productive load are considered a minimum $500 \mathrm{~W}$ to a maximum $10 \mathrm{~kW}$ at any time in a day. It is shown in Table 1 that the poor households use almost the same level of electric load for all year round except a little change for tertiary and full-option scenarios. But on the other hand, middle-income and rich households use an extra load for cooling purposes in the summer season and some other reliable loads which require a maximum of $500 \mathrm{~W}$ for operating for $24 \mathrm{~h}$.

3.4. Estimation of Cost for Grid Extension. Cost of grid extension is estimated by using a linear equation depending on the number of connections $(N)$ and length of the grid extension $(L)$ :

$$
\text { Cost }_{\text {grid }}=c_{1} L+c_{2} N \text {. }
$$


TABLE 1: Electric load demand estimation.

\begin{tabular}{|c|c|c|c|c|}
\hline Types of load & Primary & Secondary & Tertiary & Full option \\
\hline Poor households (50) & $\begin{array}{l}\text { Lighting load for } 5-10 \mathrm{pm} \\
\text { in the evening: } 2 \times 10 \mathrm{~W}\end{array}$ & $\begin{array}{l}\text { Same as primary } \\
\text { scenario }\end{array}$ & $\begin{array}{c}2 \mathrm{~h} \text { in the morning and } \\
5 \mathrm{~h} \text { in the evening: } 2 \times 10 \mathrm{~W}\end{array}$ & Same as tertiary \\
\hline $\begin{array}{l}\text { Middle-income } \\
\text { households ( } 42 \text { ) }\end{array}$ & $\begin{array}{l}\text { Electric load for } 5 \mathrm{~h} \text { in the } \\
\text { evening time: } 3 \times 10 \mathrm{~W} \text { of } \\
\text { light, } 2 \times 40 \mathrm{~W} \text { of fan in } \\
\text { summer, and } 1 \mathrm{TV} \text { of } 80 \mathrm{~W}\end{array}$ & $\begin{array}{l}\text { Same as primary } \\
\text { scenario }\end{array}$ & $\begin{array}{l}\text { Lighting load for } 8 \mathrm{~h}: 3 \times 10 \mathrm{~W} \text {, } \\
\text { fan load in summer for } 18 \mathrm{~h} \text { : } \\
2 \times 40 \mathrm{~W} \text {, and } 1 \mathrm{TV} \text { of } 80 \mathrm{~W} \text { : } \\
10 \mathrm{~h} \text { in a day }\end{array}$ & $\begin{array}{c}\text { Same as tertiary including } \\
80 \mathrm{~W} \text { extra load for } 10 \mathrm{~h} \\
\text { in a day }\end{array}$ \\
\hline Rich households (16) & $\begin{array}{l}\text { Electric load for } 5 \mathrm{~h} \text { in } \\
\text { the evening time: } 4 \times 10 \mathrm{~W} \\
\text { of light, } 3 \times 40 \mathrm{~W} \text { of fan in } \\
\text { summer, and } 1 \mathrm{TV} \text { of } 80 \mathrm{~W}\end{array}$ & $\begin{array}{l}\text { Same as primary } \\
\text { scenario }\end{array}$ & $\begin{array}{l}\text { Lighting load for } 8 \mathrm{~h}: 4 \times 10 \mathrm{~W} \text {, } \\
\text { fan load in summer for } 18 \mathrm{~h} \text { : } \\
3 \times 40 \mathrm{~W} \text {, and } 1 \mathrm{TV} \text { of } 80 \mathrm{~W} \text { : } \\
10 \mathrm{~h} \text { in a day }\end{array}$ & $\begin{array}{c}\text { Same as tertiary including } \\
500 \mathrm{~W} \text { extra load for the } \\
\text { whole day }\end{array}$ \\
\hline Load commercial & Nil & $\begin{array}{l}5 \mathrm{~h} \text { in the evening: } \\
500 \mathrm{~W} \text { load }\end{array}$ & $14 \mathrm{~h}$ a day: $500 \mathrm{~W}$ & Full day: $2 \mathrm{~kW}$ \\
\hline Load productive & Nil & $\begin{array}{l}\text { Maximum } 10 \mathrm{~kW}: \\
\text { in off-peak time }\end{array}$ & $\begin{array}{l}\text { Maximum } 10 \mathrm{~kW} \text { : at any } \\
\text { time in a day }\end{array}$ & $\begin{array}{c}\text { Maximum } 10 \mathrm{~kW} \text { : at any } \\
\text { time in a day }\end{array}$ \\
\hline
\end{tabular}

TABLE 2: Cost of grid extension.

\begin{tabular}{lcc}
\hline Component & Quantity & Unit cost (Apx.) \\
\hline Cost of $11 \mathrm{kV}$ line from $33 \mathrm{kV}$ grid point & $25 \mathrm{~km}$ & $\$ 3870 / \mathrm{km}$ \\
Transformer setup cost, $11 \mathrm{kVA}$ & 2 & $\$ 925$ \\
Distribution lines & 108 & $\$ 4620 /$ transformer \\
Number of households & 10 & $30 \$ /$ connection \\
Total number of productive and commercial loads (Apx.) & & $2.5 \%$ of the total capital cost \\
Cost of distribution for each household, fixture, internal wiring, etc. & &
\end{tabular}

Here, Cost $_{\text {grid }}$ is the total cost including capital cost and operation and maintenance (O\&M) cost for grid extension. $L$ is the distance from the grid extension. $N$ is the number of connections in the village. $c_{1}$ and $c_{2}$ are the grid extension coefficients with respect to the distance and number of household, respectively. The parametric values obtained from Table 2 are used for equation (1) as follows.

$$
\text { Cost }_{\text {grid }}=(3870 \times 25)+(30 \times 118)=\$ 100,290 \text {. }
$$

Therefore, the total costs of the construction of a new transmission line through grid extension for the specified village are estimated at $\$ 100,290$. Once the grid extension is executed, then the net present cost (NPC) will be increased by this amount. Further, the cost of buying power from the grid will be added along with the revenues of grid sales value. The price of electricity is $0.102 \$ / \mathrm{kWh}$ for households. It is observed that the cost of grid extension is higher due to initial construction, operation, and maintenance. This paper considered available renewable energy sources. It is evident that the solar/DG/battery system is the most compelling option from a cost perspective, showing low breakeven distances for the entire range of village sizes. The expansion of existing grid lines is not a suitable choice from both the cost-effectiveness and environmental protection perspectives.
3.5. Village Load Profile. The daily and monthly load profiles of the primary scenario are shown in Figures 5 and 6(a). Poor households do not use fans in summer; therefore, the winter load is almost half of that in summer. The baseline data shows that $21.86 \mathrm{~kW}$ is the peak load of the system for this scenario, and $63.81 \mathrm{kWh} /$ day is the average energy demand. According to HOMER, $15 \%$ is assumed as a day-to-day random variation of the load. No commercial and productive loads are considered in the primary scenario. On the other hand, for the secondary scenario, $500 \mathrm{~W}$ of the commercial load is considered to be consumed for 5 hours a day. Again, a maximum of $10 \mathrm{~kW}$ productive load is considered for this scenario during the off-peak time (between 7 am and $5 \mathrm{pm}$ ). The average baseline need for energy is $166.92 \mathrm{kWh} /$ day, and the peak load is $22.81 \mathrm{~kW}$. The secondary scenario load profile shows a better system load factor of 0.3 while the primary scenario shows the load factor of only 0.12 .

In the tertiary scenario, both the productive and residential demands are being focused on which allows any amount of load at any time of the day. Here, $500 \mathrm{~W}$ commercial load is assumed for $14 \mathrm{~h}$ a day and up to $10 \mathrm{~kW}$ productive load is considered to be consumed at any time in a day. It improves the system load factor to 0.37 because of better load distribution. The daily and monthly load profiles are shown in Figures 5 and 6(c). The daily baseline energy demand and a peak load of this scenario are $453 \mathrm{kWh} /$ day and $50.42 \mathrm{~kW}$, respectively. 


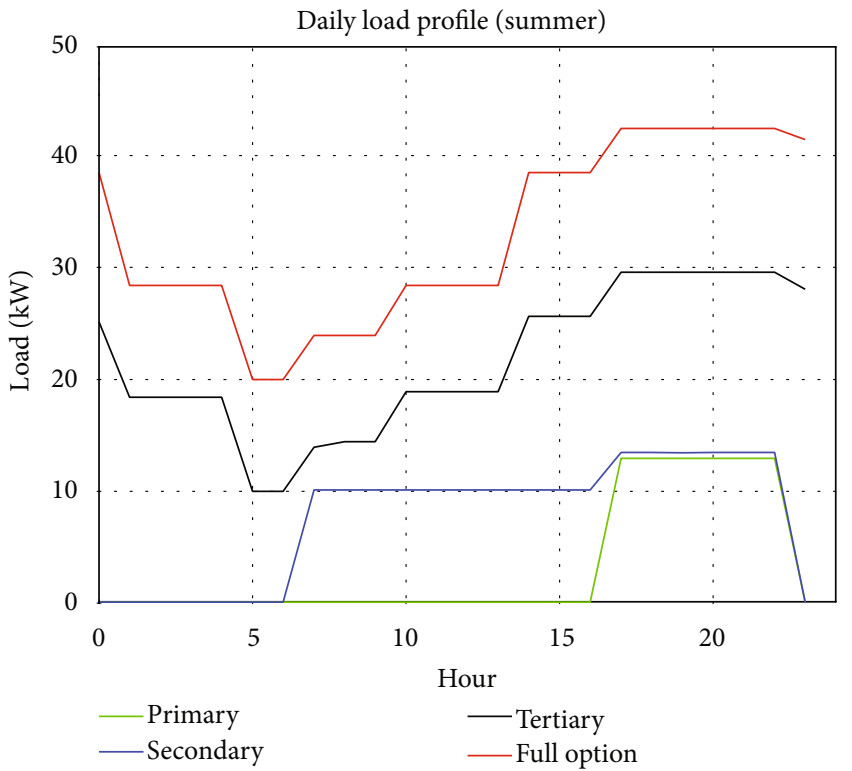

(a) Summer load

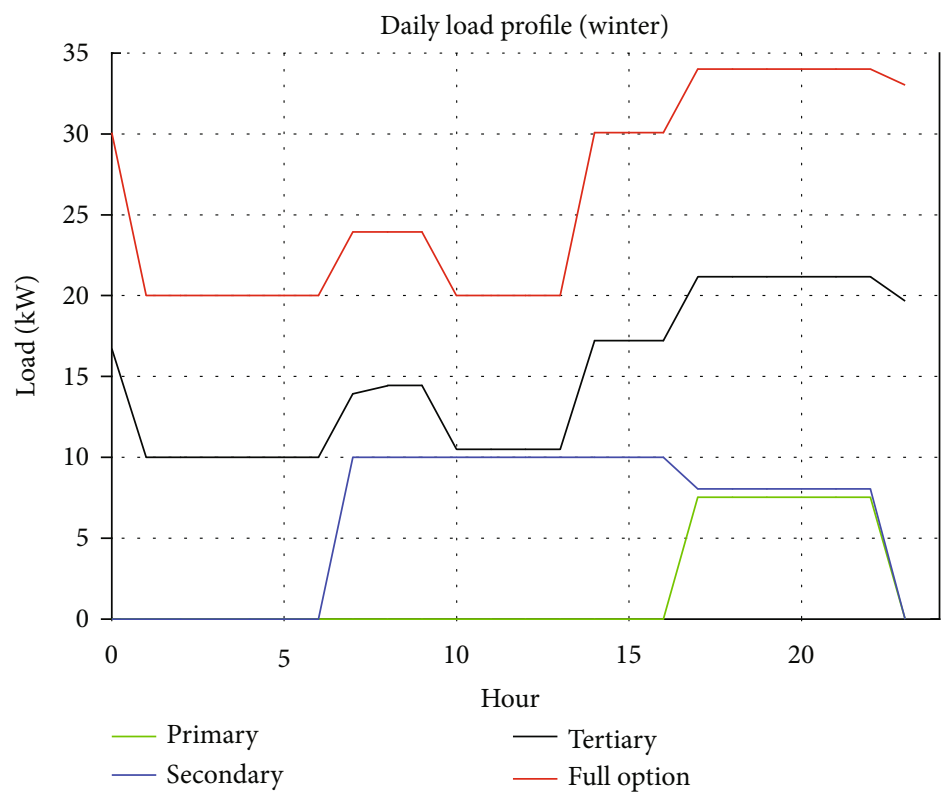

(b) Winter load

FIgURE 5: Daily load profile for all four scenarios.

For the fourth case, full-option scenario, all the restrictions are removed and provide potential development for rich households of the village. The daily average energy demand of this load profile reaches up to $722.85 \mathrm{kWh} /$ day while the peak load is $72.4 \mathrm{~kW}$. Consequently, the load factor improves to 0.42 . The daily and monthly load profiles are shown in Figures 5 and 6(d).

3.6. Solar Radiation. Solar energy is considered as the main resource for power generation in this current investigation. Along with solar PV, diesel fuel is also considered here. The solar radiation data is obtained from NASA Prediction of Worldwide Resources data access point [35]. The daily radiation and clearness index are shown in Figure 7 . It is shown that the range is between $7.7 \mathrm{kWh} / \mathrm{m}^{2}$ and $11.3 \mathrm{kWh} / \mathrm{m}^{2}$ daily. It is also observed that the higher solar irradiance is expected in the month of April to October and the lower irradiance is to be expected from November to March. But in the month of December, the solar irradiance is around $9.7 \mathrm{kWh} / \mathrm{m}^{2}$. These behaviors will be partially helpful for the tertiary and full-option load profiles. HOMER software is capable to generate a clearness index from the solar radiation data obtained from [35]. The annual average radiation is shown $9.52 \mathrm{kWh} / \mathrm{m}^{2} /$ day for the targeted location.

3.7. PV Panel. Recently, the cost of solar PV system is reduced. According to the current price in the market [36], 


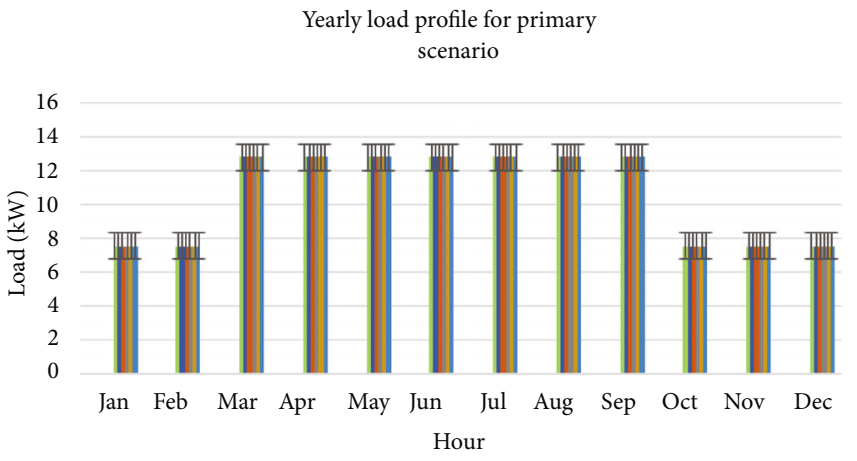

(a) Primary load

Yearly load profile for secondary scenario

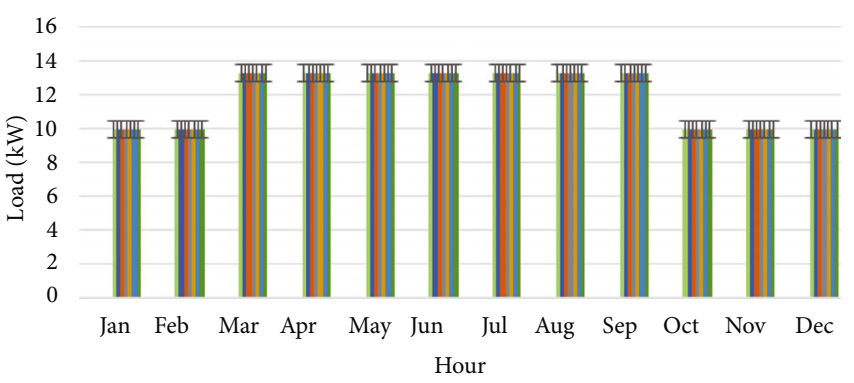

(b) Secondary load

Yearly load profile for tertiary scenario

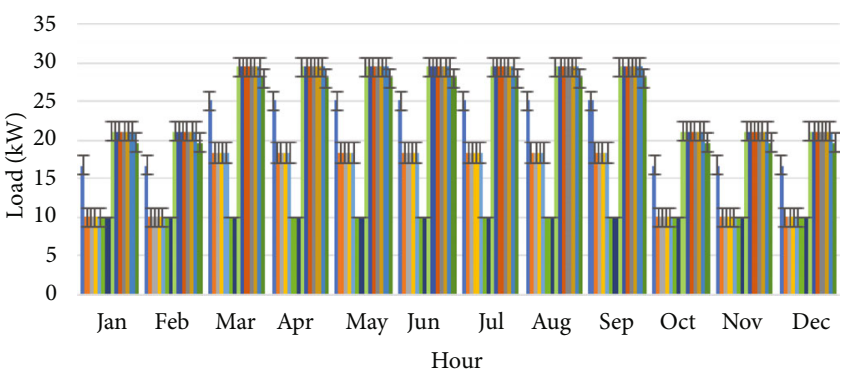

(c) Tertiary load

Yearly load profile for full-option scenario

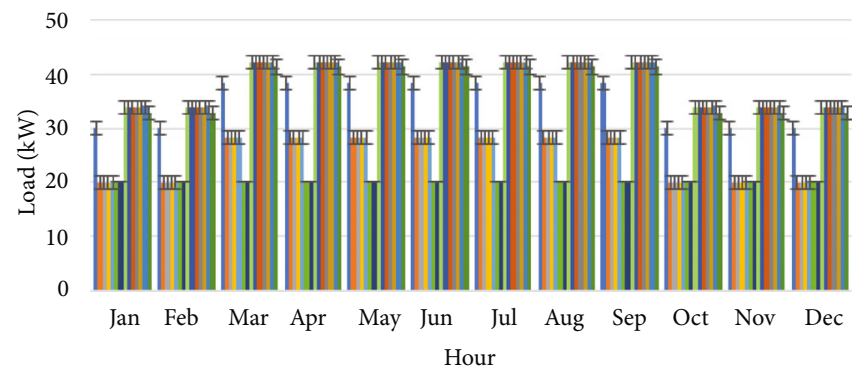

(d) Full-option load

Figure 6: Monthly load profile for all four scenarios.

the capital cost and the replacement cost of a $1 \mathrm{~kW}$ PV system are considered as $\$ 2500$ and $\$ 2000$, respectively. The operation and maintenance cost of the PV system is considered to be $\$ 10 / \mathrm{year} / \mathrm{kW}$. The lifetime of the solar
PV system is considered to be 25 years. HOMER software will facilitate optimizing the system to ensure optimal combination in terms of size and capacity of the PV system. 


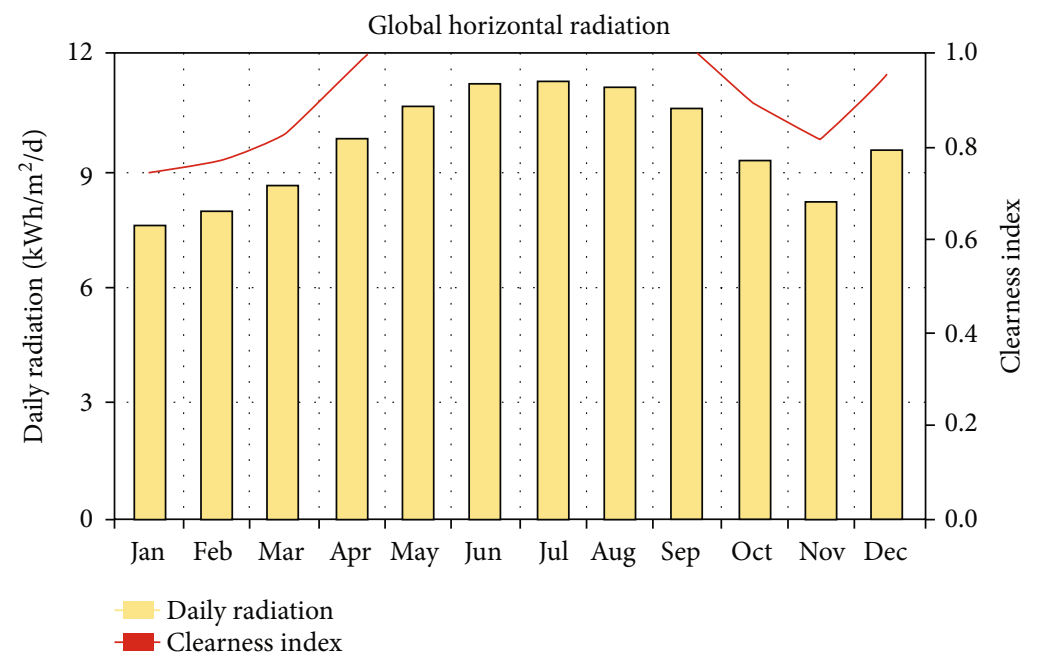

FIgURE 7: Solar radiation data of Nilgaon village in Haripur subdistrict.

3.8. Diesel Fuel. Diesel generators are mostly used as a source of electricity in other rural areas of Bangladesh. A minimum civil effort is required in this case. $\$ 600$ is considered as the capital cost of $1 \mathrm{~kW}$ of power generated from a diesel generator. Again, the replacement cost is assumed to be $\$ 500 / \mathrm{kW}$. The operation and maintenance cost of the generator is considered $\$ 0.025 /$ hour $/ \mathrm{kW}$. The national supply system is a suitable source of diesel to generate electricity by diesel generators. It is anticipated that the diesel demand of the village electrification will not cause problems in the fuel market adversely. According to the current market price, the price per liter of diesel is $\$ 0.77$.

3.9. Storage Battery. Batteries are used for energy storage purposes in the day time. Generic $1 \mathrm{kWh}$ Lead Acid ( $1 \mathrm{kWh} \mathrm{LA)}$ battery is chosen as a storage device for this hybrid system. The nominal capacity is $1 \mathrm{kWh}$ and the nominal voltage is $12 \mathrm{~V}$. The maximum capacity is $83.4 \mathrm{Ah}$ for each battery. The maximum charge and discharge current are $16.7 \mathrm{~A}$ and $24.3 \mathrm{~A}$, respectively. The lifetime of this battery is 1 decade. The initial cost and the replacement cost are both $\$ 300$ for each one. The operation and maintenance cost of the battery is assumed to be $\$ 10$ per year.

3.10. Inverter. The inverter cost is considered $\$ 200 / \mathrm{kW}$, and $\$ 150 / \mathrm{kW}$ is taken as replacement cost. It has an efficiency of $95 \%$ and lifetime is normally 15 years. It is noted that the inverter is rated according to the required capacity of the PV system. Any operation and maintenance cost of the inverter is not estimated.

\section{Operational Strategies}

It is assumed that the design system will follow some strategies. For example, the battery bank will be charged by only the PV array, not by a diesel generator. The generator will be used to serve the necessary load only. Further, the cost of the distribution network is not calculated by HOMER. It is estimated separately. The capital cost of the distribution network is considered to be $\$ 3000$ in total for all the households of the village. The fixed operating and maintenance cost is chosen as $\$ 200 /$ year.

A typical hybrid PV/diesel system is designed for the purpose of simulation as shown in Figure 8. The quantity and the capacity of the diesel generator, photovoltaic array, inverter, and battery bank depend on the different load scenarios. Actually, the PV produces DC power and is used as a baseload supply unit. An inverter converts this DC power into AC power. The PV will charge the battery bank if there is any extra power left after satisfying the regular load demands of the consumers. If the PV is unable to fulfill the regular demands, the battery will not be charged. Instead, the battery will be discharged to meet the demands. Diesel generators will be activated when both PV and battery are unable to satisfy the end-user load demand. Normally, the generators will be used most likely in the nighttime. 10\% operating reserve is considered as a percentage of hourly load, and $25 \%$ operating reserve is considered for solar power output. Operating reserve is an important issue because it would be measured as a safety margin of the hybrid system. It increases the reliability of power supply against uncertainties in terms of variable electric load and solar power supply. As an example, if there is $100 \mathrm{~kW}$ load demand at an hour and PV produces $50 \mathrm{~kW}$, then the operating reserve is $10 \mathrm{~kW}+12.5 \mathrm{~kW}=$ $22.5 \mathrm{~kW}$. Consequently, the diesel generator needs to produce $50 \mathrm{~kW}$ of electricity and an operating reserve of $22.5 \mathrm{~kW}$. Therefore, the capacity of the generator and battery reserved combined should be at least $72.5 \mathrm{~kW}$.

\section{Results and Discussion}

HOMER software package is used for the technoeconomic analysis of this hybrid renewable energy system. All the four scenarios are taken into account to produce results using HOMER and thereafter are well analyzed.

5.1. Primary Scenario. For simulation purposes, HOMER uses baseline data for optimization. As mentioned before that 


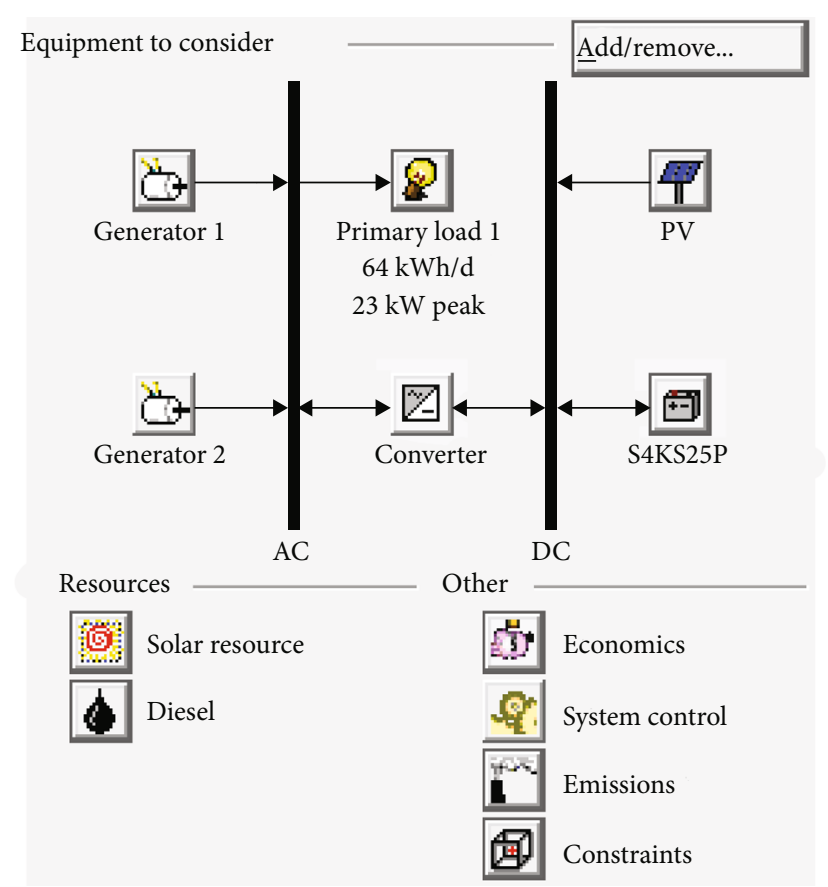

Figure 8: Typical hybrid PV/diesel system configuration.

no productive use is considered in this primary service and an electric facility is provided for evening hours only. According to the HOMER software, a $25 \mathrm{~kW}$ diesel generator is the optimal choice for this primary load profile scenario. It is obtained depending upon the availability of resources and the cost of the components. The initial capital cost of the generator is $\$ 15000$, where $\$ 0.449$ is the levelized cost or the cost of electricity (COE) per $\mathrm{kWh}$. The net present cost (NPC) and operating costs are $\$ 135,337$ and $\$ 9309$, respectively. Diesel consumption is $8606 \mathrm{~L}$ to run the generator for $2190 \mathrm{~h} /$ year, and the electricity production is $23501 \mathrm{kWh} /$ year where the average fuel consumption per day is $23.6 \mathrm{~L}$. Carbon dioxide emission is $27377 \mathrm{~kg} / \mathrm{yr}$ of this generator-battery configuration.

The AC primary load is calculated $23291 \mathrm{kWh} / \mathrm{yr}$; hence, the excess electricity production would be $211 \mathrm{kWh} / \mathrm{yr}$ which is $0.896 \%$ of net production. The life of autosize genset is calculated 6.85 years; therefore, a replacement cost of $\$ 18025.73$ is required for the continuation of electricity generation over the project life. Table 3 shows the optimized architecture and the system cost of the primary scenario when the diesel generator is chosen as the best option. Monthly average electricity production of the diesel generator for the primary scenario is shown in Figure 9.

5.2. Secondary Scenario. Depending upon the baseline data and available resources, HOMER is used to design the optimized architecture for the secondary load profile. It is already mentioned earlier that productive demand is considered in this scenario for which electricity is consumed at an offpeak time. Here, $26 \mathrm{~kW}$ diesel generator, $22.6 \mathrm{~kW}$ PV system, 57.00 strings $1 \mathrm{kWh}$ LA batteries, and a $17.6 \mathrm{~kW}$ converter are required as an optimum hybrid configuration. The initial capital cost of this hybrid system is calculated $\$ 92749$, where
$\$ 0.3$ is the levelized cost per kWh of generated electricity. The net present cost (NPC) and operating costs are $\$ 235,953$ and $\$ 11078$, respectively. Diesel consumption is $7547 \mathrm{~L}$ to run the generator for $1824 \mathrm{~h} /$ year, and the electricity production would be $77198 \mathrm{kWh} /$ year. PV system generates $73.1 \%$ (56449kWh/yr) of electricity, whereas $26.1 \%$ (20750 kWh/yr) is produced from the diesel generator and then $16.2 \%$ extra unused electricity is generated. The mean output generation of the PV system is $155 \mathrm{kWh} / \mathrm{d}$. It provides the levelized cost of $\$ 0.0815 / \mathrm{kWh}$ and operates for $4380 \mathrm{~h} / \mathrm{yr}$. During winter, the PV system produces comparatively less power. The capacity factor and cost of PV system show 28.5\% and \$59442.71, respectively. Table 4 shows the optimized architecture and the system cost of secondary scenarios when the solar-dieselbattery system is chosen as the best option.

The capacity of diesel generator utilization shows $9.11 \%$ of full power. The generator cost shows $\$ 15600.00$, but fuel and operation/maintenance costs are added to an amount of $\$ 119,438$ for the lifetime of the project. As the utilization of diesel generator shows less than $10 \%$, its total life increases to 8.22 years, and consequently, the total replacement cost would be $\$ 16376$. The nominal capacity of 57 batteries is $57 \mathrm{kWh}$ which provides the autonomy of $4.9 \mathrm{~h}$, and annual throughput is $7674 \mathrm{kWh}$. The NPC of the battery system is $\$ 59443$ in which $\$ 56520$ comes from the initial capital cost. Carbon dioxide emission is $19756 \mathrm{~kg} / \mathrm{yr}$ of this generatorbattery configuration. The monthly average electricity production of the hybrid PV/diesel system with battery in the secondary scenario is shown in Figure 10.

The second best combination contains a $35.5 \mathrm{~kW} \mathrm{PV}$ system, $2251 \mathrm{kWh}$ LA battery, and $29.5 \mathrm{~kW}$ converter. No diesel generator is recommended for this configuration. Combining other necessary costs with the initial capital cost $(\$ 162,209)$ and operating/maintenance cost $(\$ 33679)$, the total NPC shows $\$ 295,114$. The levelized electricity cost becomes $\$ 0.375 / \mathrm{kWh}$, and $100 \%$ energy is produced from a renewable source of energy in this configuration which is $88701 \mathrm{kWh} / \mathrm{yr}$.

On the other hand, a diesel-only configuration is the least attractive option in terms of net present cost and levelized rate for this secondary load profile scenario. Therefore, the PV/Gen/battery system provides the lowest levelized cost even if it is better than that of the primary scenario, because in the secondary load profile, it is shown that electric loads are distributed in a more proper way which enhances the utilization of energy resources and consequently reduces the cost of electricity generation. A comparison table is provided to observe and compare with other combinations of energy sources for this secondary scenario. It is shown in Table 5 .

5.3. Tertiary Scenario. HOMER produces the optimized configuration for the tertiary scenario of load profile. Here, $56.0 \mathrm{~kW}$ diesel generator, $43.4 \mathrm{~kW}$ PV system, 180.00 strings $1 \mathrm{kWh}$ LA batteries, and a $36.4 \mathrm{~kW}$ converter are required as an optimum hybrid configuration. The initial capital cost is calculated $\$ 203,420$ where $\$ 0.34$ is the levelized cost per kWh of generated electricity. The net present cost (NPC) and operating/maintenance cost are $\$ 769,966$ 
TABLE 3: Optimized architecture and system cost of primary scenario (net system).

\begin{tabular}{|c|c|c|c|c|c|c|c|}
\hline System & Size $(\mathrm{kW})$ & NPC (\$) & $\operatorname{COE}(\$)$ & $\begin{array}{l}\text { Operating cost } \\
(\$ / y r)\end{array}$ & Initial capital (\$) & Total fuel (L/yr) & $\begin{array}{l}\text { Carbon dioxide } \\
\text { emission }(\mathrm{kg} / \mathrm{yr})\end{array}$ \\
\hline Diesel generator & 25 & 135,337 & 0.449 & 9309 & 15000 & 8606 & 27377 \\
\hline Operating hours & $\begin{array}{l}\text { Production } \\
\quad(\mathrm{kWh})\end{array}$ & $\operatorname{Gen}(\$) \mathrm{O} \& \mathrm{M}$ cost & Fuel cost $(\$)$ & Per day fuel (L) & $\begin{array}{c}\text { Excess electricity } \\
(\mathrm{kWh} / \mathrm{yr})\end{array}$ & \multicolumn{2}{|c|}{ Replacement cost (\$) } \\
\hline 2190 & 23501 & 1369 & 6627 & 23.6 & 211 & \multicolumn{2}{|c|}{18025} \\
\hline
\end{tabular}

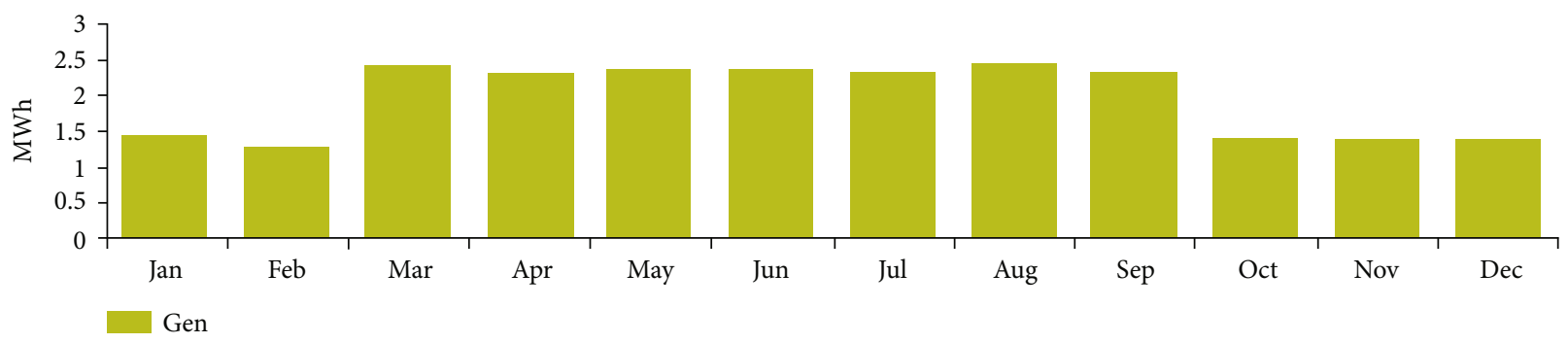

FIGURE 9: Monthly average electricity production of the diesel generator for the primary scenario.

TABLE 4: Optimized cost summary of the solar-diesel-battery system for the secondary scenario.

\begin{tabular}{|c|c|c|c|c|c|c|}
\hline Component & Capital cost $(\$)$ & Replacement cost (\$) & $\mathrm{O} \& \mathrm{M}$ cost $(\$)$ & Fuel cost $(\$)$ & Total cost $(\$)$ & Carbon dioxide emission (kg/yr) \\
\hline Autosize genset & 15600 & 16375 & 15327 & 75126 & 119,438 & 19756 \\
\hline Battery & 17100 & 31412 & 7369 & 0.00 & 52632 & \\
\hline PV system & 56520 & 0.00 & 2923 & 0.00 & 59443 & \\
\hline Converter & 3529 & 1123 & 0.00 & 0.00 & 4440 & \\
\hline System & 92749 & 48910 & 25618 & 75126 & 235,953 & \\
\hline
\end{tabular}

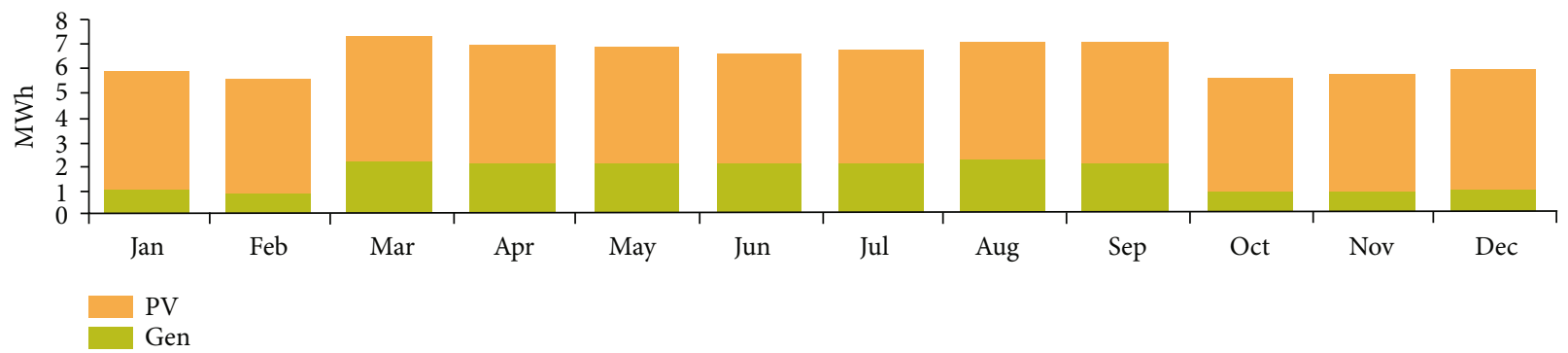

FIGURE 10: Monthly average electricity production of the hybrid PV/diesel system with battery for the secondary scenario.

and $\$ 91413$, respectively. Diesel consumption is $31798 \mathrm{~L}$ to run the generator for $3455 \mathrm{~h} /$ year, and the electricity production comes to $202,971 \mathrm{kWh} /$ year. The PV system generates $53.4 \%(108,405 \mathrm{kWh} / \mathrm{yr})$ of electricity, whereas $46.6 \%$ $(94566 \mathrm{kWh} / \mathrm{yr})$ is produced from the diesel generator and then $13.5 \%$ extra unused electricity would be generated. The mean output generation of the PV system is $297 \mathrm{kWh} / \mathrm{d}$. It provides the levelized cost of $\$ 0.0815 / \mathrm{kWh}$ and operates for $4380 \mathrm{~h} / \mathrm{yr}$. During winter, the PV system produces comparatively less power. The capacity factor and cost of PV system show $28.5 \%$ and $\$ 114,155.10$, respectively. Table 6 shows the optimized cost summary of the solar-diesel-battery system of the tertiary scenario. The monthly average electricity production of the hybrid PV/diesel system with battery in the tertiary scenario is shown in Figure 11.
As the utilization of the diesel generator shows as high as $53.4 \%$ of total power, its total life decreases to 4.34 years, and consequently, a couple of replacements are required. Therefore, the replacement cost is as high as $\$ 70666$. The nominal capacity of 180 batteries is $180 \mathrm{kWh}$ which provides the autonomy of $5.72 \mathrm{~h}$ and annual throughput is $23990 \mathrm{kWh}$. The NPC of the battery system is $\$ 114,155$ in which $\$ 108,542$ comes from initial capital cost. The mean output of the inverter and rectifier shows $9.10 \mathrm{~kW}$ and $0.956 \mathrm{~kW}$, respectively. The capacity factors of the inverter and rectifier are $25 \%$ and $2.63 \%$, respectively. Operation hours of these components are $5487 \mathrm{~h} / \mathrm{yr}$ and $3270 \mathrm{~h} / \mathrm{yr}$. Carbon dioxide emission is $83234 \mathrm{~kg} / \mathrm{yr}$ of this generator battery configuration.

The second best-optimized configuration for this tertiary scenario contains a diesel generator and battery system. The 
TABLE 5: Different architectures of energy sources and their performance for the secondary scenario.

\begin{tabular}{lcccccc}
\hline Architecture & Initial cost $(\$)$ & NPC $(\$)$ & COE $(\$)$ & Fuel cost $(\$ / y r)$ & Excess electricity $(\%)$ & Carbon dioxide emission $(\mathrm{kg} / \mathrm{yr})$ \\
\hline PV-Gen-Bat. & 92749 & 235,953 & 0.300 & 5811 & 16.20 & 19756 \\
PV-Bat. & 162,209 & 295,114 & 0.375 & 00000 & 20.80 & 0000000 \\
Gen & 15600 & 352,623 & 0.448 & 17676 & 0.633 & 60089 \\
Gen-Bat. & 15936 & 353,327 & 0.449 & 17676 & 0.633 & 60089 \\
PV-Gen & 17811 & 353,424 & 0.449 & 17557 & 2.980 & 59686 \\
\hline
\end{tabular}

TABLE 6: Optimized cost summary of the solar-diesel-battery system for the tertiary scenario.

\begin{tabular}{lccccc}
\hline Component & Capital cost $(\$)$ & Replacement cost $(\$)$ & O\&M cost $(\$)$ & Fuel cost $(\$)$ & Total cost $(\$)$ \\
\hline Autosize genset & 33600 & 70665 & 62530 & 316,522 & 481,696 \\
Battery & 54000 & 98488 & 23270 & 0.00 & 164,956 \\
PV system & 108,542 & 0.00 & 5613 & 0.00 & 114,155 \\
Converter & 7278 & 2316 & 0.00 & 0.00 & 9158 \\
System & 203,420 & 171,470 & 91413 & 316,522 & 769,966 \\
\hline
\end{tabular}

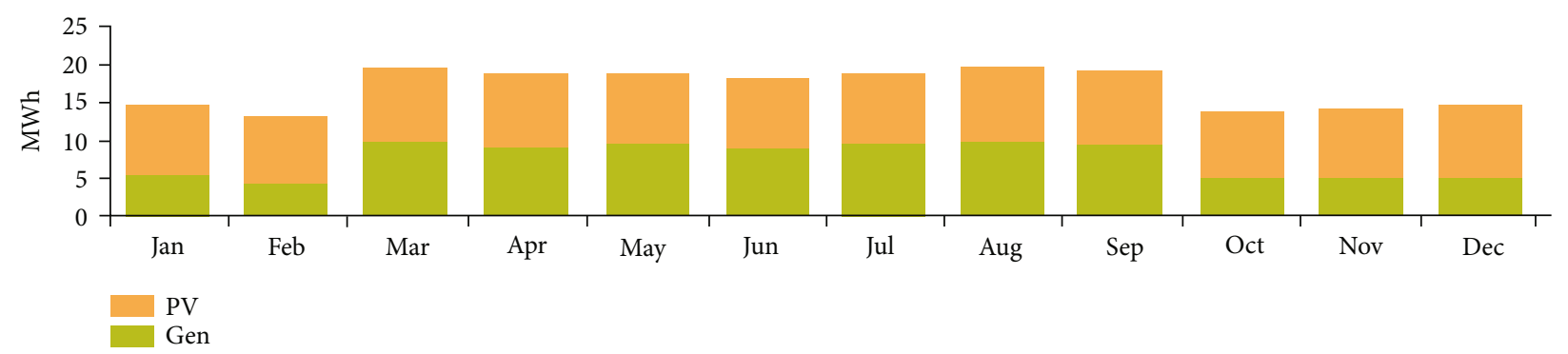

FIGURE 11: Monthly average electricity production of the hybrid PV/diesel system with battery for the tertiary scenario.

capacity of the generator is the same as earlier, which is $56.0 \mathrm{~kW}$, but the number of batteries is reduced to $47 \mathrm{kWh}$ LA. Again, the converter capacity is reduced to $11.9 \mathrm{~kW}$. No $\mathrm{PV}$ system is recommended for this configuration. Combining other necessary cost with the initial capital cost (\$50075) and operating/maintenance cost $(\$ 144,711)$, the total NPC shows $\$ 1,025,087$. The levelized electricity cost increases to $\$ 0.479 / \mathrm{kWh}$, and $100 \%$ energy is produced by a diesel generator in this configuration which is $170,191 \mathrm{kWh} / \mathrm{yr}$. The nominal capacity of a battery shows $47.0 \mathrm{kWh}$, and annual throughput is $11223 \mathrm{kWh} / \mathrm{yr}$. The average energy cost of the battery shows $0.184 \$ / \mathrm{kWh}$ which provides the autonomy of $1.49 \mathrm{~h}$. The mean output of the inverter and rectifier shows $1.09 \mathrm{~kW}$ and $1.43 \mathrm{~kW}$, respectively. The capacity factors of the inverter and rectifier are $9.17 \%$ and $12.1 \%$, respectively. Operation hours of these components are $1100 \mathrm{~h} / \mathrm{yr}$ and $7659 \mathrm{~h} / \mathrm{yr}$. Carbon dioxide emission increases as high as $160,157 \mathrm{~kg} / \mathrm{yr}$ of this generator-battery configuration. A comparison table is provided to observe and compare with other combinations of energy sources for this tertiary scenario. It is shown in Table 7.

5.4. Full-Option Scenario. The full-option scenario requires a higher capacity of diesel generator and PV system than all previous scenarios because of its high peak and average load throughout the year. HOMER produces the optimized architecture for this scenario which contains $80.0 \mathrm{~kW}$ diesel generator, $47.7 \mathrm{~kW}$ PV system, 151.00 strings $1 \mathrm{kWh}$ LA batteries, and a $32.7 \mathrm{~kW}$ converter.

The initial capital cost is calculated $\$ 219,058$ where $\$ 0.369$ is the levelized cost per kWh of generated electricity. The net present cost (NPC) and operating/maintenance costs are $\$ 1.26 \mathrm{M}$ and $\$ 170,965$, respectively. Diesel consumption is $62278 \mathrm{~L}$ to run the generator for $5619 \mathrm{~h} /$ year, and the total electricity production comes to $304,676 \mathrm{kWh} /$ year. PV system generates $39.1 \%(119,068 \mathrm{kWh} / \mathrm{yr})$ of electricity, whereas $60.9 \%(185,609 \mathrm{kWh} / \mathrm{yr})$ is produced from the diesel generator and then $10.3 \%(31316 \mathrm{kWh} / \mathrm{yr})$ extra unused electricity is generated. The mean output generation of the PV system is $326 \mathrm{kWh} / \mathrm{d}$. It provides the same levelized cost of $\$ 0.0815 / \mathrm{kWh}$ and similar operating hours of $4380 \mathrm{~h} / \mathrm{yr}$ as the tertiary scenario. The PV system produces less power in the winter season. The capacity factor of the PV system shows the same as $28.5 \%$, and its cost shows $\$ 137,432$ including all costs such as capital, replacement, and O\&M costs. Table 8 shows the optimized cost summary of the solar-diesel-battery system for the full-option scenario. The monthly average electricity production of the hybrid $\mathrm{PV} /$ diesel system with battery in the full-option scenario is shown in Figure 12. 
TABLE 7: Different architectures of energy sources and their performance for the tertiary scenario.

\begin{tabular}{lcccccc}
\hline Architecture & Initial cost (\$) & NPC $(\$)$ & COE $(\$)$ & Fuel cost (\$/yr) & Excess electricity (\%) & Carbon dioxide emission $(\mathrm{kg} / \mathrm{yr})$ \\
\hline PV-Gen-Bat. & 203,420 & 769,966 & 0.360 & 24484 & 13.5 & 83234 \\
Gen-Bat. & 50075 & $1.03 \mathrm{M}$ & 0.479 & 47112 & 0.606 & 160,157 \\
Gen & 33600 & $1.04 \mathrm{M}$ & 0.488 & 50371 & 5.62 & 171,236 \\
PV-Gen & 39591 & $1.05 \mathrm{M}$ & 0.490 & 50186 & 8.15 & 170,609 \\
PV-Bat. & 516,944 & $1.06 \mathrm{M}$ & 0.495 & 0.0000 & 24.0 & 0000000 \\
\hline
\end{tabular}

TABLE 8: Optimized cost summary of the solar-diesel-battery system for the full-option scenario.

\begin{tabular}{lccccc}
\hline Component & Capital cost $(\$)$ & Replacement cost $(\$)$ & O\&M cost $(\$)$ & Fuel cost $(\$)$ & Total cost $(\$)$ \\
\hline Autosize genset & 48000 & 181,197 & 145,279 & 619,924 & 988,316 \\
Battery & 45300 & 82028 & 19521 & 0.00 & 137,432 \\
PV system & 119,218 & 0.00 & 6165 & 0.00 & 125,383 \\
Converter & 6540 & 2081 & 0.00 & 0.00 & 8229 \\
System & 219,058 & 265,361 & 170,965 & 619,924 & $1,259,360$ \\
\hline
\end{tabular}

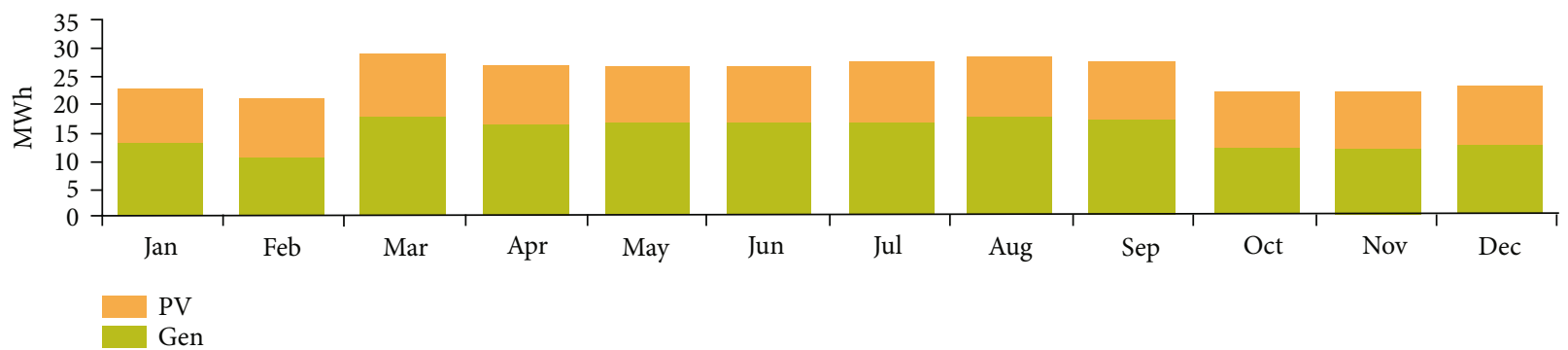

FIGURE 12: Monthly average electricity production of the hybrid PV/diesel system with battery for the full-option scenario.

The diesel generator shows high fuel consumption in this optimized configuration, and consequently, it produces $53.4 \%$ of total electric power and its lifetime decreases to 2.67 years; hence, a couple of replacements are necessary. The replacement cost of the diesel generator is $\$ 181,197$. The nominal capacity of 151 batteries is $151 \mathrm{kWh}$ which provides the autonomy of $3.01 \mathrm{~h}$, and annual throughput is $19943 \mathrm{kWh}$. The NPC of the battery system is $\$ 137,432$ in which $\$ 45300$ comes from initial capital cost. The mean output of the inverter and rectifiers shows $9.93 \mathrm{~kW}$ and $0.948 \mathrm{~kW}$, respectively. The capacity factors of inverter and rectifiers are $34.4 \%$ and $2.90 \%$, respectively. Operation hours of these components are $4742 \mathrm{~h} / \mathrm{yr}$ and $4010 \mathrm{~h} / \mathrm{yr}$. Carbon dioxide emission is $163,019 \mathrm{~kg} / \mathrm{yr}$ of this generator-battery configuration.

The second best-optimized configuration for this fulloption scenario contains a diesel generator and PV system. The capacity of the generator is the same as the most optimized architecture, which is $80.0 \mathrm{~kW}$, but no battery is used. PV capacity is reduced to $10 \%$ of the above option, which is $9.38 \mathrm{~kW}$. Again, the converter capacity is reduced to $8.03 \mathrm{~kW}$. Combining other necessary cost with the initial capital cost $(\$ 73065)$ and operating/maintenance cost $(\$ 227,703)$, the total NPC shows $\$ 1,472,584$. The levelized electricity cost increases to $\$ 0.432 / \mathrm{kWh}$, and $91.6 \%$ energy $(254,705 \mathrm{kWh} / \mathrm{yr})$ is produced by a diesel generator in this configuration and other $8.42 \%$ energy $(23430 \mathrm{kWh} / \mathrm{year})$ is produced by the PV system. The mean output of the inverter shows $1.62 \mathrm{~kW}$. The rectifier is not needed because the energy storage device is not suggested by HOMER in this configuration. The capacity factor of the inverter is $20.2 \%$. The operation hours of this device are $3516 \mathrm{~h} / \mathrm{yr}$. Carbon dioxide emission increases as high as $232,738 \mathrm{~kg} / \mathrm{yr}$ of this generator-PV configuration. A comparison table is provided to observe and compare with other combinations of energy sources for this full-option scenario. It is shown in Table 9.

\section{Analysis of Optimal Solutions}

A comparison of four scenarios for the optimal solutions shows (see Table 10) the following.

It appears that a diesel-based system is a preferable solution when no productive use is considered for the primary service and an electric facility is provided for evening hours only. Here, the demand is limited and the supply is restricted. On the other hand, the hybrid systems appear to be more appropriate when the demand improves and the supply is provided round the clock. The hybrid system considerably increases the initial investment cost.

The initial investment cost is considerable for hybrid systems. It is due to the intermittent nature of the PV and battery systems. Consequently, all hybrid systems need extra capacity which reduces the overall system capacity factor. In Table 10, it is seen that the cost per $\mathrm{kW}$ of peak load and 
TABLE 9: Different architectures of energy sources and their performance for the full-option scenario.

\begin{tabular}{lcccccc}
\hline Architecture & Initial cost $(\$)$ & NPC $(\$)$ & COE $(\$)$ & Fuel cost $(\$ / y r)$ & Excess electricity $(\%)$ & Carbon dioxide emission $(\mathrm{kg} / \mathrm{yr})$ \\
\hline PV-Gen-Bat. & 219,058 & $1.26 \mathrm{M}$ & 0.369 & 47954 & 10.3 & 163,019 \\
PV-Gen & 73065 & $1.47 \mathrm{M}$ & 0.432 & 68462 & 4.87 & 232,738 \\
Gen & 48000 & $1.48 \mathrm{M}$ & 0.434 & 71048 & 1.89 & 241,528 \\
Gen-Bat. & 48841 & $1.48 \mathrm{M}$ & 0.434 & 71048 & 1.89 & 241,528 \\
PV-Bat. & 782,441 & $1.64 \mathrm{M}$ & 0.480 & 0.0000 & 23 & 0000000 \\
\hline
\end{tabular}

TABLE 10: Comparison of the best solutions for four scenarios.

\begin{tabular}{|c|c|c|c|c|c|c|c|c|c|}
\hline \multirow[b]{2}{*}{ Scenarios } & \multicolumn{3}{|c|}{ Architecture } & \multirow{2}{*}{$\begin{array}{l}\text { Peak load } \\
\quad(\mathrm{kW})\end{array}$} & \multirow{2}{*}{$\begin{array}{l}\text { Levelized cost of } \\
\text { electricity }(\$ / k W h)\end{array}$} & \multirow{2}{*}{$\begin{array}{l}\text { Installed capacity } \\
\text { to peak load ratio }\end{array}$} & \multirow[b]{2}{*}{$\begin{array}{l}\text { Diesel use } \\
\quad \text { (liters) }\end{array}$} & \multirow{2}{*}{$\begin{array}{l}\text { Carbon dioxide } \\
\text { emission }(\mathrm{kg} / \mathrm{yr})\end{array}$} & \multirow[b]{2}{*}{ Total cost $(\$)$} \\
\hline & $\begin{array}{c}\mathrm{PV} \\
(\mathrm{kW})\end{array}$ & $\begin{array}{c}\mathrm{DG} \\
(\mathrm{kW})\end{array}$ & $\begin{array}{c}\text { Bat. } \\
(\mathrm{kWh})\end{array}$ & & & & & & \\
\hline Primary & & 25 & & 21.86 & 0.449 & 1.14 & 8606 & 27377 & 135,337 \\
\hline Secondary & 22.6 & 26 & 57 & 22.81 & 0.30 & 2.13 & 7547 & 19756 & 235,953 \\
\hline Tertiary & 43.4 & 56 & 180 & 50.42 & 0.34 & 1.97 & 31798 & 83234 & 769,966 \\
\hline Full option & 47.7 & 80 & 151 & 72.4 & 0.369 & 1.76 & 62278 & 163,019 & $1,259,360$ \\
\hline
\end{tabular}

carbon dioxide emission varies depending on the size of excess capacity maintained in each scenario and the use of diesel. It shows the remarkable periodical investment to keep the system running continuously. Although the suggested optimal PV-diesel alternative with battery might not reduce the cost of electricity (COE) and NPC significantly, it is capable to reduce dependency on diesel utilization. Utilizing less diesel helps to reduce carbon emission to the environment that helps to minimize the greenhouse effect. It is noted that the optimized PV-diesel system with the battery would consume lower fuel and it would be an economical solution with respect to other options even if the diesel price increases. Therefore, the hybrid PV/diesel system is a potential alternative for use in remote and unelectrified areas in Bangladesh.

\section{Conclusion}

In this paper, village-level electrification is considered and analysis is carried out on the viability of a hybrid power system for a remote nonelectrified peripheral village in Thakurgaon district of Bangladesh. In this analysis, different demand scenarios are developed considering the income level of inhabitants of the village. A suitable technoeconomic analysis is conducted for all the demand scenarios by using HOMER. Alternative development pathways are captured by the demand scenarios like the primary level of power supply for not more than $5 \mathrm{~h}$ per day, secondary, tertiary, and full-option supply consisting of domestic, productive, and commercial loads. The performed technoeconomic analysis suggested for optimal configurations for all four scenarios. A $25 \mathrm{~kW}$ diesel generator is suggested for the primary supply scenario as an optimal energy source. The other three scenarios are suggested for hybrid PV-diesel-battery as optimal solutions. It can be seen from the simulation that the optimum solutions significantly reduced the dependency on solely available diesel resources. The share of renewable energy starts from $0 \%$ (in the primary case) to $73 \%$ (in the secondary case) for alternative demand scenarios. However, the initial cost increases depending upon the demand and system size. Moreover, depending upon the lifetime and their extent to use, some assets (for example, diesel generators and batteries) require to be replaced during the project life. As a conclusion, the hybrid PV/diesel/battery system has potential use in remote areas in Bangladesh.

\section{Data Availability}

Data will be available upon request.

\section{Conflicts of Interest}

The authors declare no conflict of interest.

\section{Acknowledgments}

This project was funded by the Deanship of Scientific Research (DSR) at King Abdulaziz University, Jeddah, under grant no. G: 208-135-1440. The authors, therefore, acknowledge with thanks DSR for technical and financial support.

\section{References}

[1] B. Piotor, D. Antoni, and K. Bartlomiej, Hybrid solar panel fuel cell over plant, vol. 11, pp. 22-23, 2001.

[2] L. Chun-Hua, X.-J. Zhu, C. Guang-yi, S. Sheng, and H. MingRuohu, "Dynamic modeling and sizing optimization of standalone photovoltaic power systems using hybrid energy storage technology," Renewable Energy, vol. 39, pp. 815-826, 2009.

[3] T. Markvart, "Sizing of hybrid photovoltaic-wind energy systems," Solar Energy, vol. 57, no. 4, pp. 277-281, 1996.

[4] J. G. McGowan, J. F. Manwell, C. Avelar, and C. L. Warner, "Hybrid wind/PV/diesel hybrid power systems modeling and South American applications," Renewable Energy, vol. 9, no. 1-4, pp. 836-847, 1996.

[5] B. S. Borowy and Z. M. Salameh, "Optimum photovoltaic array size for a hybrid wind/PV system," IEEE Transactions on Energy Conversion, vol. 9, no. 3, pp. 482-488, 1994. 
[6] K. Karakoulidis, "Techno-economic analysis of a stand-alone hybrid photovoltaic-diesel-battery- fuel cell power system," Renewable Energy, vol. 36, no. 8, pp. 2238-2244, 2011.

[7] J. Larmine and A. Dicks, Fuel Cell Systems Explained, Wiley, England, 2nd edition, 2003.

[8] C. Bossi, A. Del Corono, M. Scagliotti, and C. Valli, "Characterisation of a $3 \mathrm{~kW}$ PEFC power system coupled with a metal hydride $\mathrm{H}_{2}$ storage," Journal of Power Sources, vol. 171, no. 1, pp. 122-129, 2007.

[9] K. R. Ajao and I. K. Adegun, "Development and power performance test of a small three-blade horizontal-axis wind turbine," Heat Transfer Research, vol. 40, no. 8, pp. 777-792, 2009.

[10] S. Salisu, M. W. Mustafa, L. Olatomiwa, and O. O. Mohammed, "Assessment of technical and economic feasibility for a hybrid PV-wind-diesel- battery energy system in a remote community of north central Nigeria," Alexandria Engineering Journal, vol. 58, no. 4, pp. 1103-1118, 2019.

[11] C. Daniel, M. Tomasz, and D. David, "Feasibility study of wind to hydrogen system for arctic remote locations - Grimsey island case study," Renewable Energy, vol. 75, pp. 745-761, 2015.

[12] S. C. Bhattacharyya, "Mini-grid based electrification in Bangladesh: technical configuration and business analysis," Renewable Energy, vol. 75, pp. 745-761, 2015.

[13] R. Sen and S. C. Bhattacharyya, "Off-grid electricity generation with renewable energy technologies in India: An application of HOMER,” Renewable Energy, vol. 62, pp. 388-398, 2014.

[14] N. M. Shan and T. C. Wei, "Assessment of economic viability for PV/wind/diesel hybrid energy system in southern peninsular Malasia," Renewable and Sustainable Energy Reviews, vol. 16, no. 1, pp. 634-647, 2012.

[15] G. Abolfazl, A. Arash, Z. Mahdi, and A. Sherif, "Techno- economic analysis of stand-alone hybrid photovoltaic-diesel battery systems for rural electrification in eastern part of Iran," Renewable and Sustainable Energy Reviews, vol. 28, pp. 456462, 2013.

[16] M. Fadaeenejad, M. A. M. Radzi, M. Z. A. AbKadir, and H. Hizam, "Assessment of hybrid renewable power sources for rural electrification in Malaysia," Renewable and Sustainable Energy Reviews, vol. 30, pp. 299-305, 2014.

[17] K. D. Saheb and K. Mustapha, "A feasibility and cost benefit prospection of grid connected hybrid power system," Renewable and Sustainable Energy Reviews, vol. 50, pp. 628-642, 2015.

[18] S. M. Shaahid, L. M. Al-Hadhrami, and M. K. Rahman, "Review of economic assessment of hybrid photovoltaicdiesel-battery power systems for residential loads for different provinces of Saudi Arabia," Renewable and Sustainable Energy Reviews, vol. 31, pp. 174-181, 2014.

[19] D. Bahtiyar, "Determination of the optimum hybrid renewable power generating systems for Kavakli campus of Kirklareli University," Renewable and Sustainable Energy Reviews, vol. 16, no. 8, pp. 6183-6190, 2012.

[20] A. J. Trappey, C. V. Trappey, G. Y. Lin, and Y.-S. Chang, "The analysis of renewable energy policies for the Taiwan Penghu island administrative region," Renewable and Sustainable Energy Reviews, vol. 16, no. 1, pp. 958-965, 2012.

[21] G. Dalton, D. Lockington, and T. Baldock, "Feasibility analysis of renewable energy supply options for a grid-connected large hotel," Renewable Energy, vol. 34, no. 4, pp. 955-964, 2009.
[22] M. Ashourian, S. Cherati, A. Mohd Zin, N. Niknam, A. Mokhtar, and M. Anwari, "Optimal green energy management for island resorts in Malaysia," Renewable Energy, vol. 51, pp. 36-45, 2013.

[23] G. Dalton, D. Lockington, and T. Baldock, "Case study feasibility analysis of renewable energy supply options for small to medium-sized tourist accommodations," Renewable Energy, vol. 34, no. 4, pp. 1134-1144, 2009.

[24] S. Ahmed, Wind Energy: Theory and Practice, PHI Learning Pvt, New Delhi, India, 2011.

[25] A. Ataei, M. Biglari, M. Nedaei et al., "Techno- economic feasibility study of autonomous hybrid wind and solar power systems for rural areas in Iran, a case study in Moheydar village," Environmental Progress \& Sustainable Energy, vol. 34, no. 5, pp. 1521-1527, 2015.

[26] J. Xing, P. Ren, and J. Ling, “Analysis of energy efficiency retrofit scheme for hotel buildings using eQUEST software: a case study from Tianjin, China," Energy and Buildings, vol. 87, pp. 14-24, 2015.

[27] K. Irshada, K. Habiba, and N. Thirumal, "Energy and cost analysis of Photo Voltaic Trombe wall system in Tropical climate," Energy Procedia, vol. 50, pp. 71-78, 2014.

[28] M. T. Ke, C. H. Yeh, and J. T. Jian, "Analysis of building energy consumption parameters and energy savings measurement and verification by applying eQUEST software," Energy and Buildings, vol. 61, pp. 100-107, 2013.

[29] M. J. Khan and M. T. Iqbal, "Pre-feasibility study of standalone hybrid energy systems for applications in Newfoundland," Renewable Energy, vol. 30, no. 6, pp. 835-854, 2005.

[30] A. Mills and S. Al-Hallaj, "Simulation of hydrogen-based hybrid systems using Hybrid 2," International Journal of Hydrogen Energy, vol. 29, no. 10, pp. 991-999, 2004.

[31] The Independentbd, A National English Newspaper, http://m .theindependentbd.com/arcprint/details/19305/2015-10-15.

[32] Bangladesh population and housing census 2011, Published by Bangladesh Bureau of Statistics (BBs) and Informatics Division (SID) Ministry of Planning Government of The Peoples Republic of Bangladesh, 2013.

[33] H. Upazila, Banglapedia, January 2019, http://en.banglapedia .org/index.php?title=Haripur_Upazila.

[34] Preliminary report on household income and expenditure survey 2016 (New), Published by Bangladesh Bureau of Statistics (BBs) and Informatics Division (SID) Ministry of Planning Government of The Peoples Republic of Bangladesh, https:// www.academia.edu/37874731/Preliminary_Report_on_ Household_Income_and_Expenditure_Survey_2016_ BANGLADESH_BUREAU_OF_STATISTICS_BBS_ STATISTICS_AND_INFORMATICS_DIVISION_SID.

[35] NASA, Prediction of worldwide energy resources, https://power larc.nasa.gov.

[36] BDSTALL, Bangladesh, http://www.bdstall.com/search/ ?term=solar+panel. 